\title{
LXXIII. On the relative heights of the levels of the Black Sea and Caspian Sea
}

\section{Messrs. Maurice Engelhardt \& Francis Parrot}

To cite this article: Messrs. Maurice Engelhardt \& Francis Parrot (1816) LXXIII. On the relative heights of the levels of the Black Sea and Caspian Sea, Philosophical Magazine Series 1, 47:217, 364-370, DOI: 10.1080/14786441608628481

To link to this article: http://dx.doi.org/10.1080/14786441608628481

里 Published online: 27 Jul 2009.

Submit your article to this journal $\lceil\pi$

Џ Article views: 2

Q View related articles $₫$ 
commence; stretching for many miles to the castward, where your ladyship admired some of them so much.

" On the southern part of this boundary*, westward of Jough Neagh, granite seenis to preponderate, and I have found red granite in abundance in the parish of Kildress; but when we enter Derry, the area for a great way to the westward is schistus, mixed with numerous quarries of stratified sandstone, and primitive limestone, blue, crystallized and unstratified.

"Had your ladyship $†$ kept by the eastern boundary of the basaltic area, it would have led you, as the area increased in width, to Magheralint, where you would have encountered a new variety of limestone, quite different from all I have mentioned, and particularly that near it at Kilmore ; the latter a brownish red, free from fints, while the Magheralin and Moira limestone, and all the strata northward, are pure white and full of flints.

"6 The country or stripe to the eastward of the basaltic and himestone line, seems mostly indurated clay $\S$, with quarries of stratified saudstone through it, and some gypsum quarries, as far as Carrickfergus, and all crossed by many whin dykes.

"This detail must be very tedious to your ladyship, but I wish to give you every opportunity of verifying my statement, whenever you may happen to approach, or pass through any of the separate systems I mention; it is upon their numbers and distinctuess from each other, that I deny the trace of any great or general operation on the surface of our globe so as to disturb it; but the observations which these facts give rise to, and the inferences to be drawn from them, must be feserved for another letter.

"I remain, with great respect,

"Your ladyship's very humble servant, i6 W. Richarnson, D.D."

LXXIII. On the relative Heights of the Levels of the Black Sea and Caspian Sea. By Messrs. Maurice Exgeleardot ard Francis Parroth.

$\mathrm{O}_{\mathrm{Ne}}$ of the chief objects of the travels of Messrs. Engelhardt and Parrot to Caucasus and to the Crimea, was to determine

* Thrs sentence I cannot cleariy conprehend: Does it mean, that in Trrone County, wear to Lough Neagh, Gruite abounds?. My Map does not show Kildress; Whore is it?. J F.

+ Un lcaving Gostord Castle. J.F. Is this Maherlin, in Duwn County? Ph. M. xxix. p. 27 t and where is it situated?. J.F.

$\$$ Query Red Marl? Ph. M. xxxix. p. 272.- J. F.

if Fxtracted from a Voyage to the Crinea and Mount Caucasals. (Feise in aie Krym und den Kintiosus.) Berlin 1815. 2 vols. -Anrutes ile Chimic et de Fhysique, tone i. Jan. 1016, p. 55. 
by a barometrical survey the relative height of the Black Sea and the Caspian Sea, and to measure the height of the most remarkable points of the chain of the Caucasus. The work in which they have published the fruits of their researches appeared at Berlin in 1815 .

The relative height of the two seas was ascertained twice; viz. 1st, in going from the Black Sea to the Caspian Sea; and 2dly, in returning from the Caspian Sea to the point of departure. Our traveliers attempted to malie corresponding ohservations at the level of the two seas; but this mode of verification succeeded very imperfectly.

The distance levelled from the mouth of the Kuhan in the Black Sea, to the mouth of the Terek on the shores of the Caspian Sea, pursuing the sinuosities of the post road which the two travellers traversed, is 990 wersts ${ }^{*}$. If a straight line, this distance would be merely 813 wersts, corresponding to about $9 \frac{1}{2}$ of difference of longitude: the two extreme points are almost under the same parallel.

All the details of this vast operation are given at full length, and seem to deserve great confilence. Cistern barometers were used; but the correction of the lerel was made by calculation; which is very easy, the interior diameter of the tube being known.

A thermometer fixed into the mounting of the instrument gave the temperature of the mercury: another thermometer at liberty made known the temperature of the air at the moment of the observation; the scales had been rectified according to the measurement known by astronomers under the name of faihom of Peru; a stand made for the purpose with a leaden wire admitted of the tubes being placed in a vertical position; an anemometer gave the direction and strength of the wind, and consequently the measurement of the degree of confidence which every partial levelling seemed to deserve. The indications of the barometer are always expressed in 100ith parts of a line, and great care was taken to compare the instruments, before, after, and during the operation: in order to aroid all etrors which might atise from derangements of this kind, the observers met every two dars. They remained long enough at every station to take four distinet baronetrical heights, and at intervals of $15^{\prime}$ at least: the epochs of these observations always corresponded perfectly. Every hour of the day is not equally favourable in this kind of measurement; but it did not depend on the travellers to select the hour of twelve at noon, which is generally that which answers best. Their observations, however, were

* 104.3 wersts make 1 " of the meridian. 
always made between six in the morning and eight in the evening.

It may be easily supposed from all these precautions that $M$. Parrot must have calculated his operation with great care: thus he made use of the formula of M. Laplace and of the coefficient 18393 metres which M. Ramond had found in the Pyrenees, almost under the very same parallel with the Caucasus, having in view at the same time the capillary depression of the mercury. The only correction of which he could not keep an account was that of the diminution of gravity.

The number of stations comprehended between the mouth of the Kuban and that of the Tcrek is 51 ; they were, therefore, distant from each other about 18 versts or 13 miles. The first measurement commenced on the 13 th of July, beginning with the island of Taman*, and proceeding eastward, ascending the Kuban to Batal-Paschinsk near Constantinogorks, where the 29 th station was. Our travellers set out from this point to

* The isle of Taman is remarkable by its springs of asphaltus, and its foaming volcanoes, which have been partly described by Pallas in his Travels of 1709 and 1794. Messrs. Parrot and Engelhardt visited the small volcanoes situated between the city of Taman and the lake Sucur. On the slope of a hill they discovered two basins of 16 metres aperture and two metres and a half deep, and which were filled with a frothy mass formed of argil and water. From time to time they saw rise to the surface of each crater a bubble of air about a foot in diameter: the instant it burst a great number of similar small balls took its place. This phænomenon was repeated every 30 or 40 seconds. The temperature of the water differed little from that of the air: the water at $29^{\circ} 4^{\circ}$ of the centigrade thermoncter, the thermometer in the sun marked $2.99^{\circ}$, and in the shade $26.9^{\circ}$. The travellers wanted proper instruments for examining the nature of the air extricated by the crater; they merely ascertained that it was not inflammable, and that it did not keep up combustion. The water, which was yellowish, had a saltish taste: in the bottom were found fragments of bituminous limestone, selenite, and quartzous freestone. It seems that these sinall basins underwent some considerable changes at the time of the great eruption which took place in 1794 in the northern part of the bay of Taman. In 1807 near Kurgan the Cossacks heard a subterraneous roise similar to a discharge of artillery. The mountain was enveloped with a thick smoke; but specdily they saw issue slowly from the bowels of the yawning earth a new hill, as large as a house. Large masses of calcareous stone were thrown about here and there, but no flame was perceived. In the vicinity ufar Bugos, fountains of asphaltus or liquid mineral tar were found, which issue from secondary layers of freestone and schistous limestone.

These phenomena of frothy volcanoses put us in mind of that of Cumacatar, on the coast of Paria; the argillaceous and impregnated plains of Chapapote (asplialtus and petroleum) of the Island of Trinity; the foaming volcanoes of Girgenti in Sicily, celebrated by the ancients; and particularly the volcanoes of Turbace, ncar Carthagena in New Spain, and which according to $M$. Humboldt send forth azotic gas much purer thau is generally obtained in the laboratories of the chemists. 
make excursions in the Caucasus, which lasted from the 17 th of August to the $3 \mathrm{~d}$ of October, and during which they measured the Kasbeck, a peak as high as Mount Blanc. They resumed their labours on the 4th of October, and continued them following the 'Terek to the delta which it forms in throwing itself into the Caspian Sea. The highest point in this operation was only 59.4 metres above the Taman Island. In the vicinity of Mosdock, one of the stat:ons, and 250 wersts from the Caspian Sea, the plain was on the level of the Black Sra.

This first measurement was made under very favourable circumstances, and gave for the difference of level 105 metres by which the Caspian Sea is lower than the Black Sea.

Struck with the singularity of this result, Messrs. Parrot and Fngelhardt recommerred the operation of the 10th of October, but proceeding on this occasion from east to west and following the same stations, without turning towards the Caucasus. On the 14th of October they had already gained the mouth of the I Kubar. The weather during this second measurement was much less favourable, the barometer and thermometer were inconstant, the changes more sudden, the winds more variable and of more unequal strength. Snow also fell at various times: the sky was generally stormy, cold, and rainy, circumstances which usually render the altitudes too small. Now it is remarkable that it is in fact in this respect that the second determination is erroneous, for it gives 92 metres for the elevation of the level of the Black Sea over that of the Caspian Sea.

After having thus twice traversed the great Steppe, M. Parrot had the patience to make a third journey. He set out from Taman on the 24 th of November, and ought to have arrived at the mouth of the Terek on the 10th of December. The want of post horses produced so many delays, however, that he did not reach the banks of the Caspian Sea until the 20th of December at 15 minutes past 11 A.M. M. Engelhardt had finished his observation on the Black Sea the night before: thus this operation presents no corresponding observations, and may merely serve as a verification. On combining the observation of Taman of the 19 th at 15 minutes past 11 with the observation made next day at the same hour in the Caspian Sea, we find 99 metres for the difference of level. Another observation made at Taman in the afternoon of the 19th of December gave 102 metres. On comparing the observation of M. Parrot of the 20th with the me:n of all the observations of the 19 th on the Black Sea, we shall obtain almost the same difference. There is in short no barometrical observation from that of 15 minutes past 11 made at Taman from the 11 in to the 19 th of December, which combined with the single observation of M. Parrot of 
the 20th of December indicates a sensible difference of lerel between the two seas: the least of these determinations will not be less than 41 metres.

After having ascertained this grand difference of level, our travellers thought they should inequire if it had always existed. Now Pallas thought he recognised by the form of the strata and the shells of the Caspian Sea scattered throughout the Steppe the ancient shores of that sea. The operations of Messis. parrot and Engelhardt plice these shores, which have an inmense development, and in which we find gnlfs and bays very clearly defined, at 234 nutres above the present level; it must therefore be admitted that a mass of water has been lost of about 30,000 square sea leagues in surface and 100 metres in depth. M. Parrot does not think that this was by evaporation; for, according to Gmelin, the waters of the Caspian 'Sea are so little salt that they do not contain one fourth of the muriate of soda which is found in those of the Atlintic Ocean: he rather thinks that this water must have run off by rents which have been successively opened and closed, the bottom of the sea being agitated by the volcanic action, the effects of which are still seen in the Island of Taman on the Bosphorus, and at Baka on the Caspian Sea. The enormous differences between the soundings observed since 1556 and the time of Petcr the Great to the present time give some probability to this opinion*.

Let us now refer these results to the operations of the same lind which have been made at different epochs in order to compare the Red Sea with the Mcditerranean, the Mediterranean with the Atlantic Ocean, and this Occan with the Sonth Sea.

During the French expedition in Egypt, a commission of engineers of ronds and bridges was cliarged under the direction of M. le Pere to execute the levelling of the Isthnus of Suez: thereby they resolved the celebrated question agitated from the most remote antiquity, of the elevation of the Red Sea above the Mediterranent and the soil of Lower Lgypt. It results, in fact, from the labours of the commission, that the level of the

* On taking the mean between the rexults of the two measurements we shall find 982 millibetres (wear 200 fect) for the quantity by which the level of the Black Sea is more clevated than that of the Caspiati Sea. Ilence it results that Astracan, the urijecrnt plains, and a very urcat number of other inhaluter places as woll in Persin as in Russia, are much infering to the level of the Black sea and the Meditermenean:- the singularity of this result will justify the detilis into which we bare cotered. To conclude: Before the royge of Nenrs, Parrot and Engelhardt, it had been suspected that the two seats bad always one aud the sane level. M. Parrot's measuremeat correspond's perfectly with that given by Dr. Thos. Young in bis Natural Plitosophy. The barometrical heigbts of Kamychin

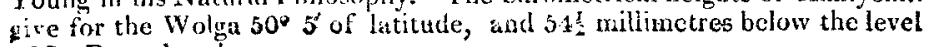
of St, Petersburgh. 
Mediterranean Sea is lower by eight millimetres at low water and nine millimetres at the high water of the Red Sea. One part of the basin of the bitter lakes is remarkable for its boing eight metres lower than the level of the Mediterranean, which conseguently places it $\mathbf{1 6}$ metres lower than the Red sea: other points of the soil and even of the inhahited places are lowerthan the levels of both seas. The water of the Red Sea, for instance, might cover the whole of the surface of the Delta, and the terrors of submersion were, as has been seen, natural enough at distant periods, when this part of Egypt was less elevated than it is at present.

For want of observations exactly correspondent for estimating the difference of elevations of two very distant stations, experimentalists have sometimes used the comparison of the barometrical mean pressure: this process is capable of much precision, as M. Ramond has demonstrated, if we stop at the mean pres. sures of the same hours, in order to avoid the effects of the periodical variations. In order to determine the relative altitudes of the levels of the South Sea and of the Atlantic Ocean, it ought therefore to be sufficient to compare the mean heights of the barometer over the two opposite coasts of $\Lambda$ merica. $M$. Humboldt's Journal furnishes us with the necessary data for this purpose.

In faet, we there find in the first place that at Carthagena ond Cumana in the Gulf of Mexico, the mean pressure of the barometer $=0.7620$ millimetre by a temperature of $25^{\circ}$ centigrade. At the harbour of Vera Cruz, the thermometer being at $20^{\circ}$. the height $=0.7613$ millimetre, but corrected from the dilatation of the mercury, it becomes as at Cumana 0.7620 millimetre. At the temperature of zero and at the level of the Atlantic Ocean, between the tropics, the mean height of the barometer is consequently $=0.7585$ millimetre.

On the shores of the South Sea, at Callao, a port of Lima, M. de Humboldt found the barometer $=0.7606$ millimetre, the thermometer $20^{\circ}$; and at Acapulco, still on the Pacific Ocean, the barometer $=0.7617$ millimetre, the thermonseter $27^{\circ}$. These heights brought to the temperature of zero, yield for the mean pressure of the air at the level of the South Sea $0 \cdot 7578$ millimetre. If the slight difference which we remark between this number and that which represents the mean pressure at the level of the Atlantic Ocean could not be attributed to the errors inevitable in such delicate observations, it will result that the South Sea must be higher than the Qcean by about seven metres. Other observations of $\mathrm{M}$. Humboldt which have not yet been published, will give a difference a little greater and in the same proportion; but this celebrated, traveller who only used his baVol. 47. No. 217. May 1816. A a rometers 
rometers for a geological level, thinks that in order completely to do away the doubts which the question may still present respecting the relative height of the two oceans, we must have recourse to instruments more precise, and exposed to shorter journeys by land; while we keep an account at the same time of the unequal heights of the tides, of the different hours of the observations in the harbours on the opposite shores of America, and of the horary variations of the barometer, which, although very regular as to the hours at which they happen, are not as completely so as has been supposed as to the quantities which measure them. However this may be, the observations which we have given already prove, that if there does exist a difference of level hetween the Ocean and the Great Pacific, it must be verv small.

The little velocity and constancy which mariners have remarked in the currents of the Straits of Gibraitar, show that in these places the Mediterranean and the Ocean have nearly the same level. It may nevertbeless appear curious to compare un der this point of view two very distant points, since, contrary to all idea, the levelling of the isthmus of Suez, the results of which have been given above, has proved that two seas which communicate with each other may, nevertheless, have very different levels. Now the measurement of the meridian of France presents an uninterrupted chain of triangles, which extend from Dunkirk to Barcelona; the relative elevations of the various summits may be deduced from the reciprocal observations of distances from the zenith; the absolute height of one single station will therefore serve to find the absolute height of all the rest; and this will be the case, whether we set out from the Mediterranean to approach the Ocean, or follow a contrary direction.

It is according to this method that M. Delambre has calculated the elevation of Rhodes over the Mediterranean and the Ocean, setting out in the first place from Mont Juy to Barcelona, of which Stephani had directly found the height; and secondly, by the help of a signal at Dunkirk which was only 66 metres from the level of low water: those two determinations agreeing within a fraction of a metre, we may conclude, if not that the level of the Ocean at Dunkirk is exactly the same with the level of the Mediterranean at Barcelona, at least that the inequality of height, if it exists, ought to be insensible. 